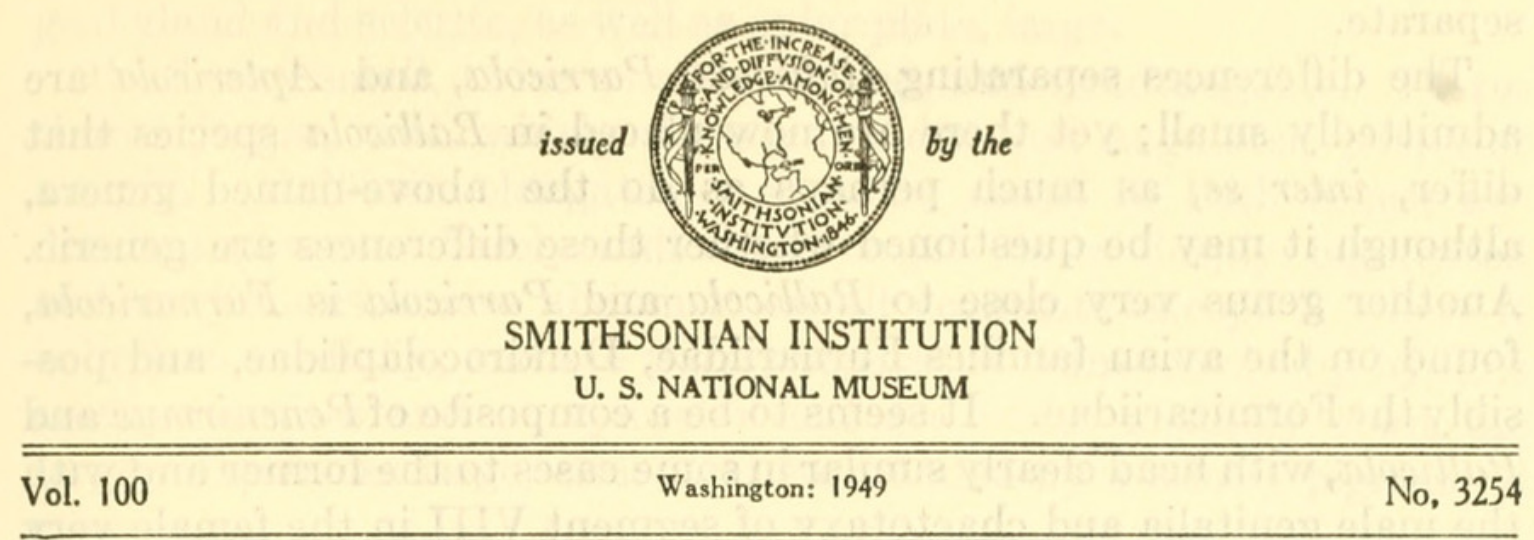

\title{
ON A COLLECTION OF MALLOPHAGA FROM GUAM, MARIANAS ISLANDS
}

By M. A. Carriker, Jr.

The collection of Mallophaga treated in this paper was made by Lt. Rollin H. Baker during World War II while he was a member of the U. S. Naval Medical Research Unit No. 2, assisted by other members of the unit. The birds from which the lice were collected are in the United States National Museum, and their correct names were furnished me by Dr. Herbert Friedmann, curator of the Museum's division of birds.

Though small, the collection is an interesting one, for it represents the first time any Mallophaga have been taken from birds indigenous to the island of Guam. Twelve species of birds are represented among the hosts, four of which are sea birds (not indigenous), one is an introduced form (Streptopeliabitorquata dusumieri), and the remaining seven are indigenous. The correct determination of the Mallophaga involved has, in some instances, been difficult, since the pertinent material is in various museums in Europe; in these cases it is possible that errors have been made. The drawings were prepared by the author. All measurements are in millimeters.

\section{Suborder ISCHNOCERA}

\section{Family PHILOPTERIDAE}

\section{CORVICOLA, new genus}

Genotype.-Corvicola insulana, new species.

This genus is close to Rallicola Johnston and Harrison as now defined. It seems to contain some very aberrant forms, such as $R$. 
funebris (Nitzsch), but the species of this group are very difficult to separate.

The differences separating Rallicola, Parricola, and Aptericola are admittedly small; yet there are now placed in Rallicola species that differ, inter se, as much perhaps as do the above-named genera, although it may be questioned whether these differences are generic. Another genus very close to Rallicola and Parricola is Furnaricola, found on the avian families Furnariidae, Dendrocolaptidae, and possibly the Formicariidae. It seems to be a composite of Penenirmus and Rallicola, with head clearly similar in some cases to the former and with the male genitalia and chaetotaxy of segment VIII in the female very close to the latter. Just how this development has come about is impossible to explain, since the host families are definitely very far apart.

Another species that superficially resembles Rallicola (as now defined) is Oncophorus unguiculatus Piaget, and it has been placed tentatively in that genus by Hopkins and Clay, but I think wrongly. Its host is supposed to be Eurylaemus ochromelus, from the Malay Peninsula and the East Indies and belongs to a family very far from the rails and kindred birds. The type species of the new genus here proposed has a striking resemblance to $O$. unguiculatus Piaget, as will be seen by comparing the figures of the two, which are, I am sure, congeneric. It may even come to light in the future that the alleged host of $O$. unguiculatus was cited in error and that its true host is some species of Corvidae, closely related to Corvus.

Diagnosis of genus Corvicola.-Medium-sized, with large, deeply pigmented head, thoracic and abdominal markings, more or less "nirmoid" form of head and body, the male equal in size to or larger than the female.

The head is suggestive of some types of Brüelia, except that the antennae are very strongly dimorphic. In the male the first segment of the antenna is thick and long, equal in length to the remaining four segments, and has on the under side a well-developed tubercle bearing a spine; the second is half the length of first, while the third is very short and produced inwardly into a long, strong hook; the fourth and fifth are minute. In the female the antennae are quite normal, with the first two segments equal in length and the last three shorter.

The head has the preantennary region uniformly rounded, with no trace of clypeal suture and with the clypeal bands widely separated anteriorly by a large clear area, which contains a small, quadrangular, faintly pigmented signature. The internal clypeal bands are fused with the marginal bands at their anterior ends, then run backward along the sides of the clypeal signature, and then circle outward and around to the anterior mandibular condyle. Faintly pigmented 
occipital bands are present, not reaching to occipital margin. Pharyngeal gland and sclerite, as well as gular plate, large.

Prothorax small, twice as wide as long, and quadrangular. Pterothorax larger, with widely divergent sides and angulated posterior margin. Abdomen elongated-oval, same shape in both sexes; abdominal pleurites barely indicated; tergal plates deeply pigmented and continuous across abdomen on all segments except I, where it is broken medially, and are widely separated transversely by hyaline areas; sternites end at spiracles and are wider medially than the tergites; spiracles large, clear, and surrounded by a faintly pigmented area.

In the female tergites I and II are broken medially; sternites absent except for a triangular plate lying under tergites VI and VII.

The vestiture of the whole body is rather sparse, with a few long hairs at the posterior angles of abdominal segments and a sparse row of medium-sized hairs along the posterior margins of tergites and sternites. In the female the vestiture of the whole body is of much finer texture, the hairs being very slender.

The male genitalia consist of a short basal plate and strong, welldeveloped, nearly straight parameres; endomeral plate small and simple and penis large.

In the female the shape and chaetotaxy of abdominal segment VIII are practically identical with those of Rallicola, with a curving line of short bristles across the upper portion of ventral face of the segment and with two long, slender spines running back from the anterior angle of the segment, the inner spine twice the length of the outer; also a cluster of about eight hairs of uneven length just posterior to the lateral spines.

Legs have large coxae, well-developed trochanters, small femora, and long, strong tibiae. The third coxae are entirely posterior to the pterothorax, being attached on inner side to its posterior margin and on the outer side to the acetabular bar, which is anchored well into segment I of abdomen.

\section{CORVICOLA INSULANA, new species}

Figure $1, a-d$

Types.-U. S. N. M. No. 58957, male and female adults, from Corvus kubaryi, collected by Rollin H. Baker on Guam Island (Marianas), July 21, 1945.

Diagnosis. - The description as given under the diagnosis of the genus above, together with the figures presented, will fully characterize the species. It is a very striking form, with its strongly dimorphic antennae, bold and deeply pigmented markings on a hyaline base, and characteristic abdominal sclerites, together with the peculiar male genitalia and the chaetotaxy of segment VIII in the female. 
The type series consists of 14 males and 13 females collected from four different individuals of the type host, between May 26 and July $21,1945$.

MEASUREMENTS OF TYPES OF CORVICOLA INSULANA

\begin{tabular}{|c|c|c|c|c|}
\hline \multirow{2}{*}{ Structure } & \multicolumn{2}{|c|}{ Male } & \multicolumn{2}{|c|}{ Female } \\
\hline & Length & Width & Length & Width \\
\hline Body & 1. 63 & - & 1.56 & . \\
\hline fat antennae... & (n) & 0.326 & & 0.38 \\
\hline Head $\{$ at temples..... & .52 & .456 & .53 & .456 \\
\hline Prothorax & .195 & .163 & .152 & .303 \\
\hline Pterothorax ............ & .24 & .436 & .26 & .48 \\
\hline Abdomen & .84 & .52 & .81 & .63 \\
\hline Antennae (seg. 1-2 in $\delta$; in $\%$ entire) & .22 & .068 & .217 & .04 \\
\hline Basal plate........ & .18 & .06 & ...... & -.... \\
\hline Parameres. & .133 & .13 & ....... & \\
\hline Endomera & .07 & .054 & -..... & (n) \\
\hline
\end{tabular}

\section{Genus RALLICOLA Johnston and Harrison}

RALLICOLA GUAMI, new species

Figure $1, e, f$

Types.-U.S. N. M. No. 58958, male and female adults, from Rallus owstoni, collected by Rollin H. Baker on Guam Island (Marianas), January 26, 1945.

Diagnosis.-This species belongs in the group comprising bisetosus (Piaget), californicus (Kellogg and Chapman), affinis (Piaget), and attenuatus (Nitzsch), being perhaps closest to the first two. I have specimens of species of Rallicola, as yet undetermined, from Gallirallus (New Zealand), Pardirallus (Peru), Ionornis (Colombia), Aramides (two species, Brazil and Colombia), Laterallus (two species), and Rallus longirostris subsp.

Apparently the species of Rallicola found on the true rails form a very compact and closely related group. Those from Fulica are of a different type; a third type is from Laterallus albigularis cinereiceps. As in the others of this group, there is a slight dimorphism in the antennae, the first segment of the male being almost as long as the second, while in the female it is only half as long. The clypeal signature extends beyond the ends of the clypeal bands and is convex in front, and the whole frons is encircled by a wide hyaline flap, beginning at the ends of the clypeal bands; the signature is almost circular, only the sides being slightly flattened. The clypeal bands are strongly sinuate along the darkened inner edge and are slightly broken at the suture; the inner bands, which support the signature, bend outward to the marginal bands and are fused with them just behind their 

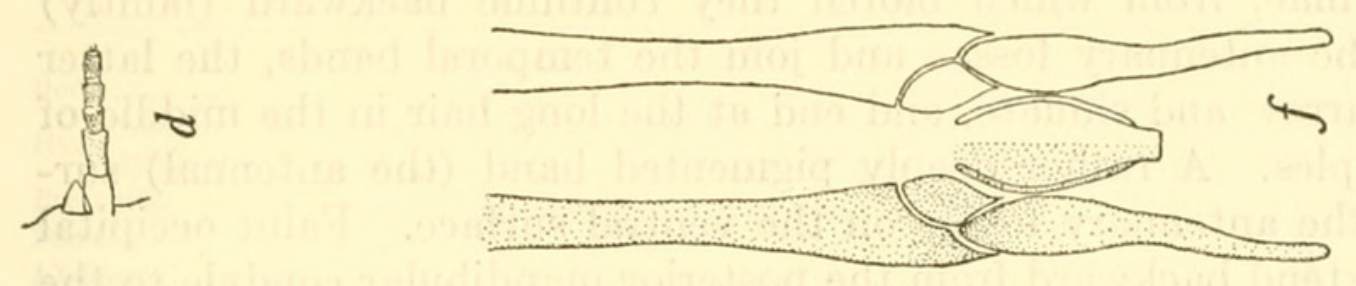

تే

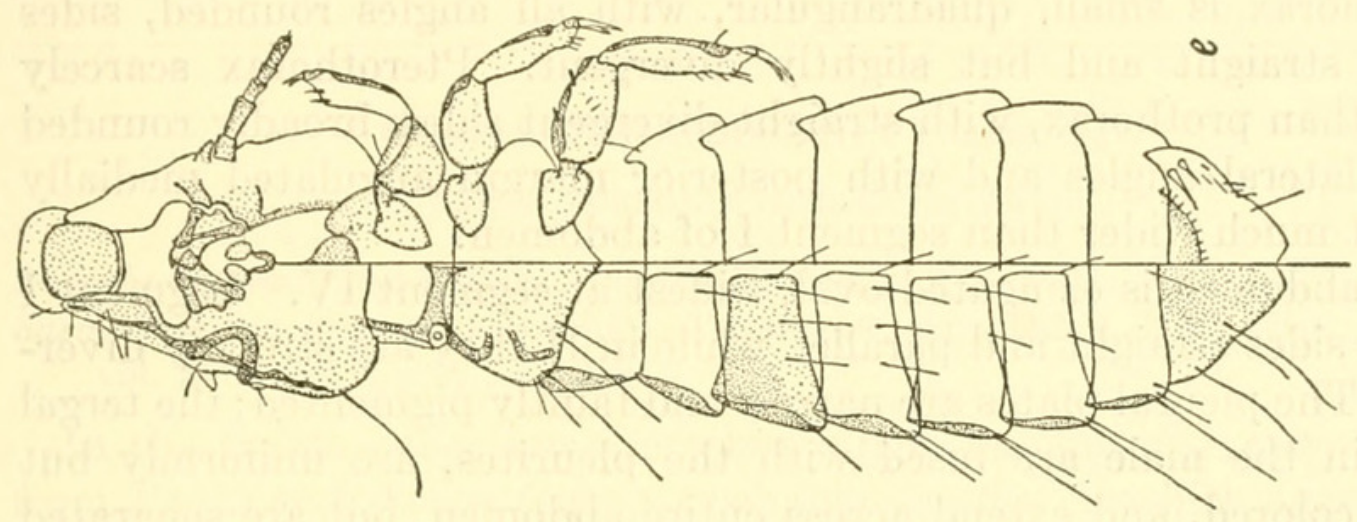

苂

茨

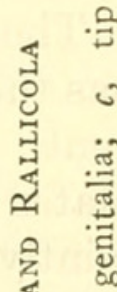
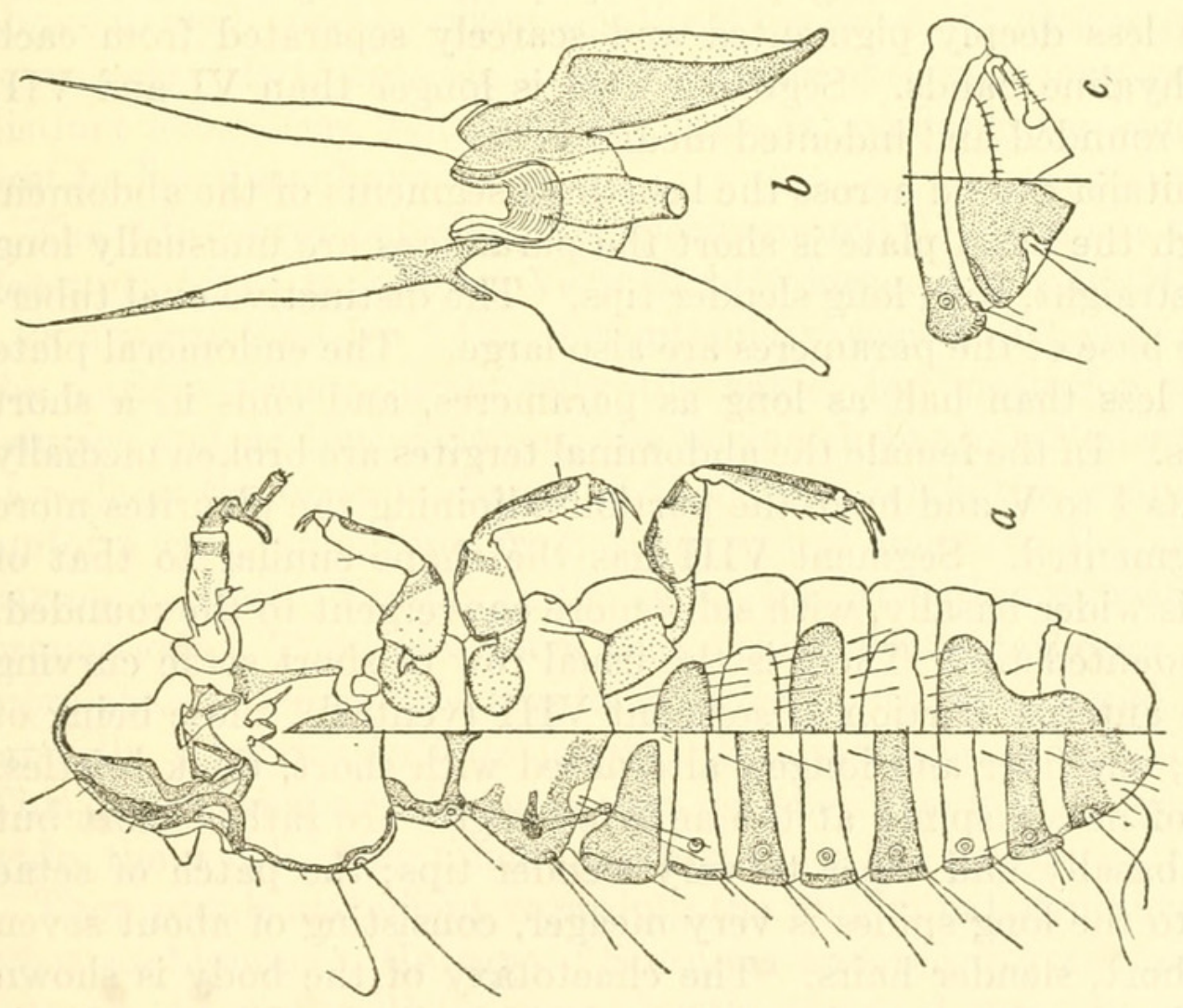

过 峁



ชั

1. के

-i 苂 吕

哇

空

造

ऽ

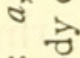

$\ddot{j}$

.

के :

恣

के

2

ปี.

. ญ

용

iा ए 
middle, then curve inward again to mandibles, where their ends form the anterior mandibular condyle; the marginal clypeal bands are not deeply pigmented except along their inner edge and a blotch at base of antennae, from which blotch they continue backward (faintly) across the antennary fossae and join the temporal bands, the latter being narrow and sinuate, and end at the long hair in the middle of the temples. A rather deeply pigmented band (the antennal) surrounds the antennary fossae on the ventral surface. Faint occipital bands extend backward from the posterior mandibular condyle to the anterolateral angles of the prothorax, which lie at some distance under the head.

Prothorax is small, quadrangular, with all angles rounded, sides almost straight and but slightly divergent. Pterothorax scarcely longer than prothorax, with straight divergent sides, broadly rounded posterolateral angles and with posterior margin angulated medially and not much wider than segment I of abdomen.

The abdomen is elongated oval, widest at segment IV. Segment I has the sides straight and parallel, while in II they are strongly divergent. The pleural plates are narrow and faintly pigmented; the tergal plates in the male are fused with the pleurites, are uniformly but faintly colored, and extend across entire abdomen, but are separated by hyaline bands widening posteriorly progressively. The sternal plates are less deeply pigmented and scarcely separated from each other by hyaline bands. Segment VIII is longer than VI and VII, with apex rounded and indented medially.

The genitalia extend across the last three segments of the abdomen, and though the basal plate is short the parameres are unusually long and very straight, with long slender tips. The distinctive oval tubercles at the base of the parameres are also large. The endomeral plate is simple, less than half as long as parameres, and ends in a short thick penis. In the female the abdominal tergites are broken medially in segments $I$ to $\mathrm{V}$ and have the portion adjoining the pleurites more deeply pigmented. Segment VIII has the shape similar to that of male but is wider basally, with sides more convergent to the rounded, slightly indented tip. There is the usual row of short setae curving across the anterior portion of segment VIII (ventral), these being of two kinds, one finer and longer, alternated with short, thick bristles. The pair of heavy spines at the anterior angles are rather short but are thick basally and taper to very slender tips; the patch of setae posterior to the long spines is very meager, consisting of about seven or eight short, slender hairs. The chaetotaxy of the body is shown correctly in the figure and need not be described. The species is represented only by the male holotype and female allotype. 
MEASUREMENTS OF TYPES OF RALLICOLA GUAMI

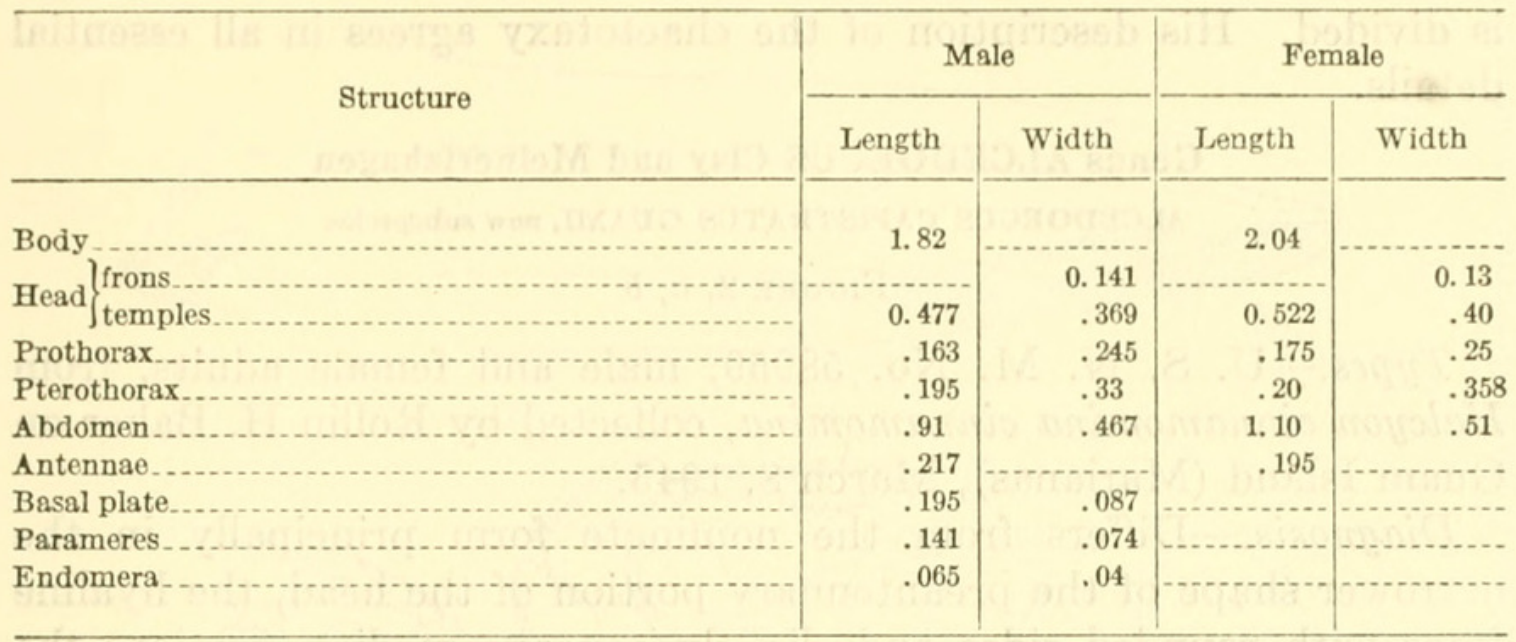

\section{Genus SAEMUNDSSONIA Timmerman}

SAEMUNDSSONIA HEXAGONA (Giebel)

Docophorus hexagonus Giebel, Insecta Epizoa, p. 176, 1874.

Saemundssonia hexagonus (Giebel), Thомpson, Ann. Mag. Nat. Hist., ser. 11, vol. 2, p. 458, figs $1,3 \mathrm{~b}, 1938$.

In the Guam collection there is a single female of Saemundssonia from Phaëthon lepturus (subsp. probably dorotheae), which agrees very closely with Thompson's description and figure of specimens of the above-named species taken on the type host, Phaëthon rubricauda roseotincta. It is possible that this single specimen may represent a distinct subspecies, but until the male is available for study it had best be listed as above.

The differences between this specimen and Thompson's figure and description are as follows: Very slightly larger (immaterial), 2.98 by 1.28 against 2.80 by 1.12 . Preantennary region of head, as well as the various bands, practically the same, but posterior portion of temples and occiput different, the occiput being much narrower, only as wide as the occipital bands at their base, while the temples form a uniform circular outline from their widest point to the side of the narrow occiput. Prothorax the same, but pterothorax with different proportions. Thompson says that "the meso-metathorax is a little more than twice as broad as long (referring to the female), widening laterally to about half its length, then tapering to a blunt point." This general shape is the same, but my specimen is 0.43 long by 0.74 wide, the width being much less than twice the length.

Thompson's statement regarding the abdominal structure is somewhat ambiguous. He says: "Sternites and tergites apparently continuous, divided medially except for the terminal ones; the first almost meet." In my specimens the tergites and sternites are fused with the narrow pleurites, while the sternites are all continuous across the abdomen, but tergites II to VI are divided medially. No. I is narrow 
medially, but not divided, while VII and VIII are continuous and IX is divided. His description of the chaetotaxy agrees in all essential details.

\section{Genus ALCEDOECUS Clay and Meinertzhagen}

ALCEDOECUS CAPISTRATUS GUAMI, new subspecies

\section{FiguRe $2, a, b$}

Types.-U. S. N. M. No. 58959, male and female adults, from Halcyon cinnamomina cinnamomina, collected by Rollin $\mathrm{H}$. Baker on Guam Island (Marianas), March 8, 1945.

Diagnosis.-Differs from the nominate form principally in the narrower shape of the preantennary portion of the head, the hyaline frons with rounded sides and slightly concave median portion; the portion of the clypeal bands in front of clypeal suture is much larger, both longer and wider.

The thorax and abdomen seem to be about the same, although it is not possible to make an intelligent comparison of some details owing to the meagerness of Neumann's description and figure. He says, for example: "Metathorax arrondi aux angles, aigu sur l'abdomen," yet in his figure he shows this segment as flatly convex posteriorly. In guami it is flatly convex.

The present race differs from the unnamed form figured by Miss Clay (from Halcyon leucocephala) in the structure of the clypeal bands, the pleurites of the abdomen, and the abdominal chaetotaxy. In Clay's figure the inner clypeal bands, which support both the clypeal signature and the portion of the outer clypeal band anterior to the suture, are shown as widely separated from the marginal bands, while in guami the two are touching each other from the base of the inner bands to the clypeal suture. The abdominal chaetotaxy of the new race seems to be exactly the same as shown by Neumann for capistratus, but the tergites in guami also have their inner ends broadly rounded, not pointed, as shown by Neumann.

MEASUREMENTS OF TYPES OF ALCEDOECUS CAPISTRATUS GUAMI

\begin{tabular}{|c|c|c|c|c|}
\hline \multirow{2}{*}{ Structure } & \multicolumn{2}{|c|}{ Male } & \multicolumn{2}{|c|}{ Female } \\
\hline & Length & Width & Length & Width \\
\hline Body & 1.37 & & 1.69 & \\
\hline Head $\left\{\begin{array}{l}\text { at trabeculae } \\
\text {. }\end{array}\right.$ & & 0.34 & & 0.38 \\
\hline Prothorax................ & $\begin{array}{l}.51 \\
.15\end{array}$ & $\begin{array}{l}.467 \\
.282\end{array}$ & $\begin{array}{l}.54 \\
.174\end{array}$ & $\begin{array}{l}.50 \\
.305\end{array}$ \\
\hline Pterothorax & .163 & .41 & .20 & .46 \\
\hline Abdomen .............. & .673 & .52 & .95 & .65 \\
\hline Antennae..... & .185 & ...... & .195 & \\
\hline Basal plate................. & .19 & .061 & ........ & $\ldots$ \\
\hline Parameres.............. & .07 & .05 & & \\
\hline Endomera.......... & .06 & .08 & & \\
\hline
\end{tabular}



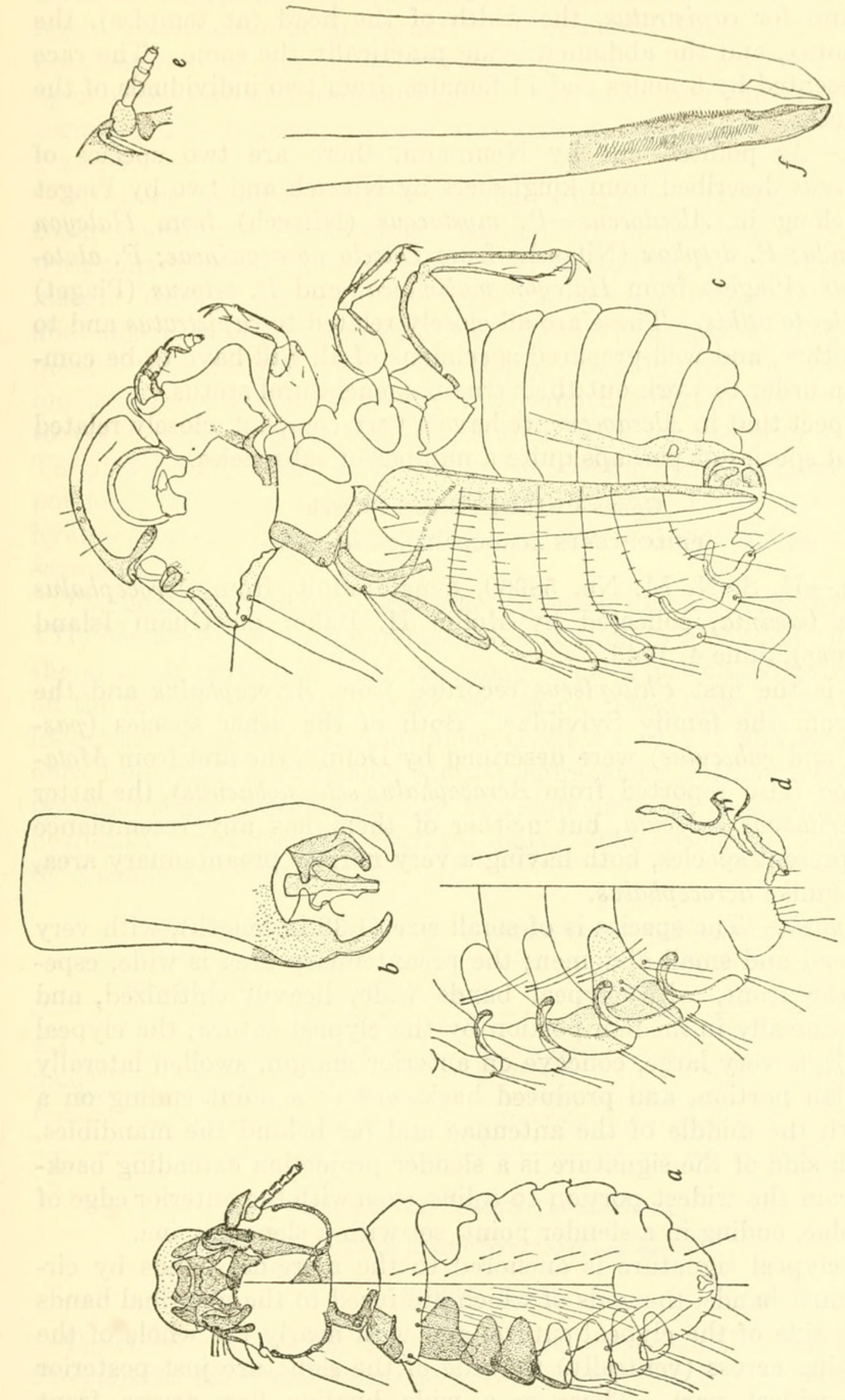
The genital armature of guami is somewhat different from that figured by Clay. In size guami is very close to measurements given by Neumann for capistratus, the width of the head (at temples), the metathorax, and the abdomen being practically the same. The race is represented by 8 males and 11 females, from two individuals of the same host.

Note-As pointed out by Neumann, there are two species of Philopterus described from kingfishers by Nitzsch and two by Piaget that belong in Alcedoecus - P. mystaceus (Nitzsch) from Halcyon coromanda; $P$. delphax (Nitzsch) from Dacelo novaeguineae; $P$. alatoclypeatus (Piaget) from Halcyon malimbica; and P. setosus (Piaget) from Alcedo atthis. These are all closely related to capistratus and to one another, and well-prepared specimens of all will have to be compared in order to work out their true nomenclatural status.

I suspect that in Alcedoecus we have a very compact, closely related group of species or perhaps quite a number of subspecies.

\section{Genus PHILOPTERUS Nitzsch}

PHILOPTERUS ACROCEPHALUS, new species

Type--U. S. N. M. No. 58960, female adult, from Acrocephalus luscinia luscinia, collected by Rollin H. Baker on Guam Island (Marianas), June 4, 1945.

This is the first Philopterus recorded from Acrocephalus and the third from the family Sylviidae. Both of the other species (passerinus and rubeculae) were described by Denny, the first from Motacilla alba (also reported from Acrocephalus schoenobaenus), the latter from Erithacus rubecula, but neither of them has any resemblance to the present species, both having a very narrow preantennary area, totally unlike acrocephalus.

Diagnosis.-The species is of small size (1.38 in length), with very large head and small abdomen; the preantennary area is wide, especially the front, with clypeal bands wide, heavily chitinized, and broken dorsally in median portion by the clypeal suture; the clypeal signature is very large, concave on anterior margin, swollen laterally in median portion, and produced backward to a point ending on a line with the middle of the antennae and far behind the mandibles. On each side of the signature is a slender projection extending backward from the widest portion to a line even with the anterior edge of trabeculae, ending in a slender point, set with a slender spine.

The clypeal signature is anchored to the marginal bands by circular, inner bands, the ends of which are fused to the marginal bands on each side of the clypeal suture, and with nearly the whole of the band lying across (ventrally) the side of the signature just posterior to the widest part. There is a wide hyaline flap across front of head, beginning at the tips of the clypeal bands, with rounded sides 
and concave front (same as signature). There is a strong hair at the tip of each clypeal band and another, longer, on the inner edge at the lateral constriction of the signature, with a small spine near it. Trabeculae are long, heavy, and curving and end in a point nearly at the apex of the second antennal segment; antennae long and heavy, with segments 2 to 5 deeply colored and with strong bristles on segments 1 and 2 .

Prothorax small and rather rounded, with heavy lateral bands and coxal markings. Pterothorax considerably wider but very short, with convex sides, rounded lateral angles, and flatly rounded posterior margin thickly set with 18 very strong, pustulated hairs. The abdomen is almost round ( 0.715 by 0.65 ), with narrow, deeply pigmented pleurites and with paler tergites extending but halfway to the median line of abdomen, ending in a rounded point, and set with four to eight very long, strong, pustulated hairs on posterior margins. Tergites I to VI are overlapped by succeeding sclerites along outer portion. There is a series of long dorsal hairs across the median hyaline portion of the abdomen, along the posterior margins of the segments.

The genital sclerite is very large, covering much of segments $\mathrm{V}$ to VII, has a circular anterior margin, and ends in a rounded point in the anterior portion of VIII; two long, coarse, pustulated hairs occur on the lateral portion of the genital plate. There are small, more or less oval sternal plates lying under tergites I to VII and two larger ones under VIII; also long sternal hairs along median portion of posterior edge of segments I to IV; segment VIII is large, rounded posteriorly, and deeply incised medially. The species is represented by a single female, the type.

MEASUREMENTS OF TYPE OF PHILOPTERUS ACROCEPHALUS

\begin{tabular}{|c|c|c|c|c|c|}
\hline Structure & Length & Width & Structure & Length & Width \\
\hline Body ........ & 1. 38 & & Pterothorax........ & .174 & .423 \\
\hline Head frons_... & ........ & 0.217 & Abdomen.... & .716 & .65 \\
\hline Head temples.. & .564 & .50 & Antennae..... & .228 & \\
\hline Prothorax ...... & .185 & .27 & Trabeculae.... & .13 & .054 \\
\hline
\end{tabular}

\section{Genus COLOCERAS Taschenberg}

COLOCERAS STREPTOPELIAE, new species

\section{Figure 2, $e-f$}

Types.-U. S. N. M. No. 85961, male and female adults, from Streptopelia bitorquata dusumieri, collected by Rollin H. Baker on Guam Island (Marianas), July 6, 1945.

Diagnosis.-This species is close to Goniodes aegypticum Kellogg and 
Paine, which should be placed in Coloceras, ${ }^{1}$ inasmuch as it has the same type of antennal dimorphism and male genitalia attributed to that genus.

The head is typically goniodian in shape, with no outstanding characters except the antennae of the male, the curious structure of the temporal angles, and certain chaetotaxy. The antennae are typical of Colocaras, having the first segment globular, the second almost as long as the first but slightly conical; the third almost as long as the second, with base same thickness as apex of second and with outer side straight and inner side bulging out to form the thickened apex; fourth and fifth are minute, fourth as thick as tip of third, fifth much smaller. In the female the first segment is globular, but smaller at tip; second is slightly shorter than first with tip thicker than base, while segments 3,4 , and 5 are about half the length of second and almost equal in length; the third being slightly the longest.

On the temples of both sexes the lateral temporal band is heavily chitinized, extends backward behind the posterior margin of temples (at the angle), and bears at its tip a short, slender spine. Just inside this projection, on the dorsal surface, is the somewhat squarish temporal angle, which bears a very long, thickened hair.

In the male the large hyaline eye bears a very long, thickened hair, while in the female it bears only an insignificant bristle. The clavi are prominent in both sexes and bear a long, strong hair. The thorax is small, the prothorax being narrow, with sides straight, slightly serrated, and divergent. The pterothorax has rounded sides and round posterior angles and has the posterior margin produced medially into a rounded extension, which bears two long, coarse hairs, while there are two other strong hairs on each side just inside the lateral angle.

There is little distinctive about the abdominal structure, except that segment $I$ is much more deeply pigmented than the remainder. However, the male genitalia as well as the female genital plate are peculiar and characteristic and are figured. The structure of the genitalia is peculiar, but not unique, since it is typical of the genus, and something analogous is found in several species now placed in Goniodes. The parameres (?) are merely elongated extensions of the heavily chitinized bands bordering the basal plate, and the combined structure is longer than the entire abdomen, the base of the basal plate reaching to the middle of the pterothorax. The tips of the parameres are serrated along their inner edge and rugose on the upper surface, while the sac lying between them contains many fairly large Y-shaped spicules. The genitalia proper lie within a thin-walled

\footnotetext{
${ }^{1}$ In my opinion the genus Margaritenes Kéler (genotype: Goniodes eurygaster) is a synonym of Coloceras. Also, Goniocotes chinensis Kellogg and Chapman is very likely a Coloceras; although the male is unknown, the head of the female is very typical of that genus.
} 
sheath, which extends from segment III to the tip of abdomen, from which it protrudes slightly. Its sides are faintly chitinized along the upper portion, but the apex is heavily chitinized and pigmented, with its rounded tip bearing about six strong hairs. The female genital plate covers much of the last three segments of the abdomen and has a strong, hooklike projection on each side under segment VII, which bears three heavy, curving spines along the posterior side.

The type series consists of 11 males and 15 females, collected from four individuals of the type host. The host in not indigenous to Guam, having been introduced, but it has become fairly abundant.

MEASUREMENTS OF TYPES OF COLOCERAS STREPTOPELIAE

\begin{tabular}{|c|c|c|c|c|}
\hline \multirow{2}{*}{ Structure } & \multicolumn{2}{|c|}{ Male } & \multicolumn{2}{|c|}{ Female } \\
\hline & Length & Width & Length & Width \\
\hline Body ........ & 1.95 & & 2.39 & \\
\hline frons & & 0.58 & & 0.434 \\
\hline Head $\left\{\begin{array}{l}\text { temples } \\
\text { occiput.............. }\end{array}\right.$ & .575 & .825 & $\begin{array}{r}.64 \\
.65\end{array}$ & .955 \\
\hline Prothorax & .217 & .467 & .28 & .53 \\
\hline Pterothorax & .37 & .65 & .426 & .738 \\
\hline Abdomen & 1.06 & 1.08 & 1.42 & 1.13 \\
\hline Antennae.......... & .22 & .087 & .217 & .09 \\
\hline Genitalia & 1.30 & 1. 22 & & \\
\hline
\end{tabular}

1 Base of plate.

\section{Suborder AMBLYCERA}

\section{Family MENOPONIDAE \\ Genus EUREUM Nitzsch \\ EUREUM PACIFICUM, new species}

FigURe $3, a, b$

Type-U. S. N. M. No. 58962, male adult, from Callocalia inexpectata bartschi, collected by Rollin H. Baker on Guam Island (Marianas), July 29, 1945.

Diagnosis.-Similar to Eureum cimicodes Nitzsch in general shape and characters, but differing in many details, especially in the chaetotaxy. The setae of the entire frontal area are of much finer texture; the fringe of setae along the anterior margin of the temples is nearly twice as long; while the four long hairs on the posterior margin of the temples are much longer, reaching almost to the posterior angle of the metathorax. The gular plate is of a peculiar shape, being deeply emarginate at posterior end, and bears along each side a series of about eight strong hairs of considerable length, very slender 
apically; there are six strong hairs around the rounded posterior angles of the prothorax, but none across the median posterior margin, except one slender hair on each side of the median notch. The frons is not evenly circular as in cimicodes, but slightly pointed medially, and with a noticeable swelling at each side (see fig.).

The prothorax is proportionately much narrower and longer; the prosternal plate is very differently shaped (according to figure by Ewing) and is set with numerous short, peglike spines, thicker in anterior portion (see fig.).

The chaetotaxy of the abdomen seems to be different from E.cimicodes, according to the description by Ewing (Proc. U.S. Nat. Mus., vol. 77 , art. 20, p. 11,1930). He says:" Dorsal setae rather short and hairlike, pleural tufts pronounced ... Ventral abdominal setae swollen at their bases and tapering to an exceedingly fine point." In the present species a series of medium-sized hairs occur on the posterior margins of the tergites, about as long as the width of the succeeding segment but alternated with a short, slender spine. At the posterior angles of the narrow pleurites I to VII are two heavy spines, not mentioned in any description of cimicodes. The setae along the posterior margin of the sternites are quite contrary to the description by Ewing, consisting of only short, slender hairs of uniform length and having no "setae swollen at their bases and tapering to an exceedingly fine point." Perhaps one of the most striking differences between cimicodes and the new species is the absence of spines along the margins of the tibiae, there being merely a few slender hairs on outer apical portion. Denny's enlarged figure of the legs of cimicodes, showing detailed chaetotaxy, is very different from the species here described, and there is no reason to assume that his figures are not correct.

The male genitalia are simple, with a short, slender basal plate, widening at the base and bearing long, slender, almost straight parameres.

The description given by Ewing was made from a specimen taken on Chaetura pelagica at Columbus, Ohio, and he is correct in saying that there may be some doubt that this specimen is the same species as those taken on the European swift (Apus apus). My belief is that this specimen from Chaetura pelagica will prove to be distinct from $E$. cimicodes when direct comparison can be made with European material from the type host. Also, Ewing's description was made from a female, while the type and single paratype of pacificum are both males. I doubt, however, if there will prove to be many, if any, differences between the sexes in the characters here used to differentiate the new form. In addition to the type another adult male was taken on the same host species on January 29, 1945, by Mr. Baker, and both specimens are identical. 

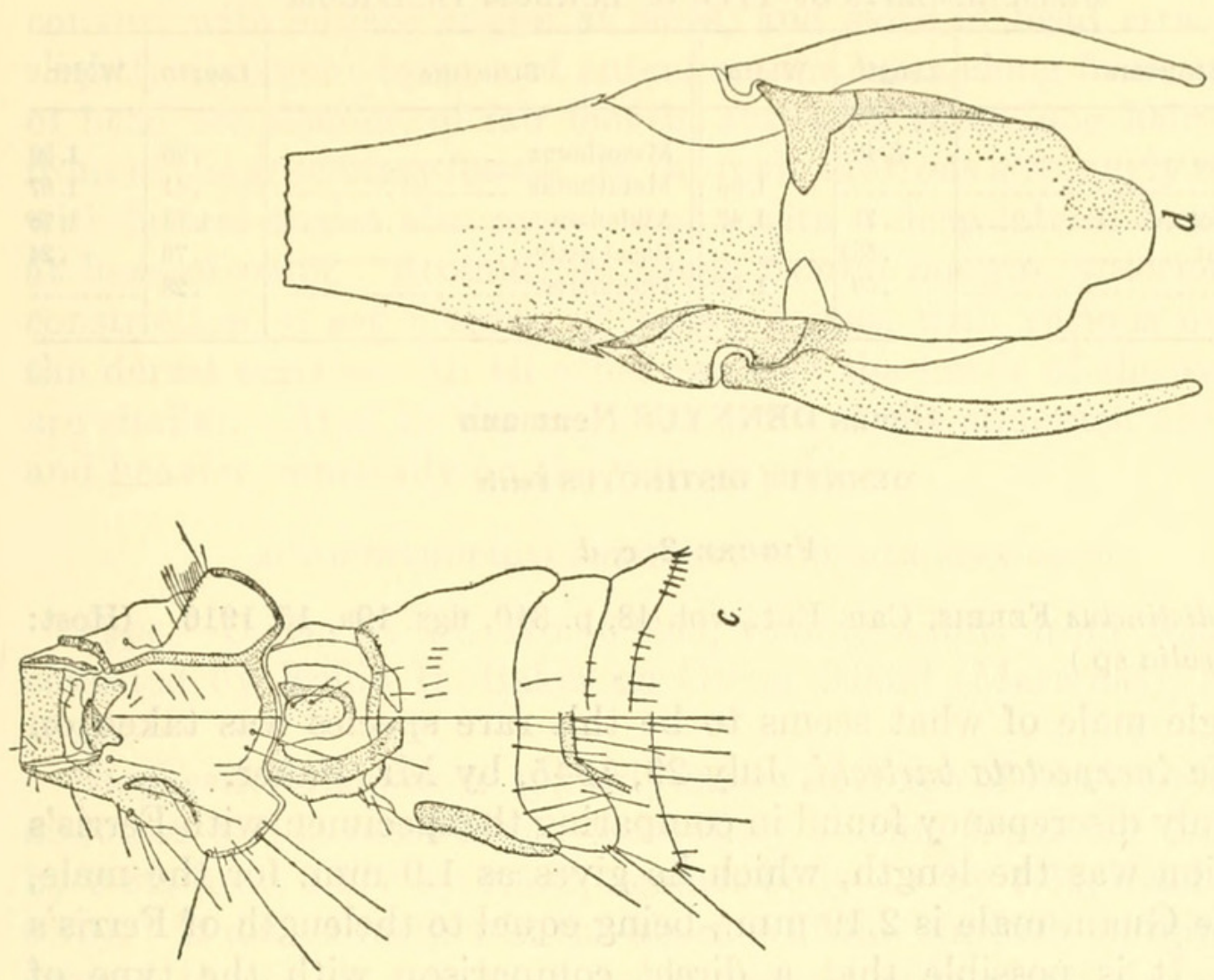

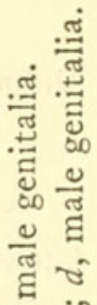

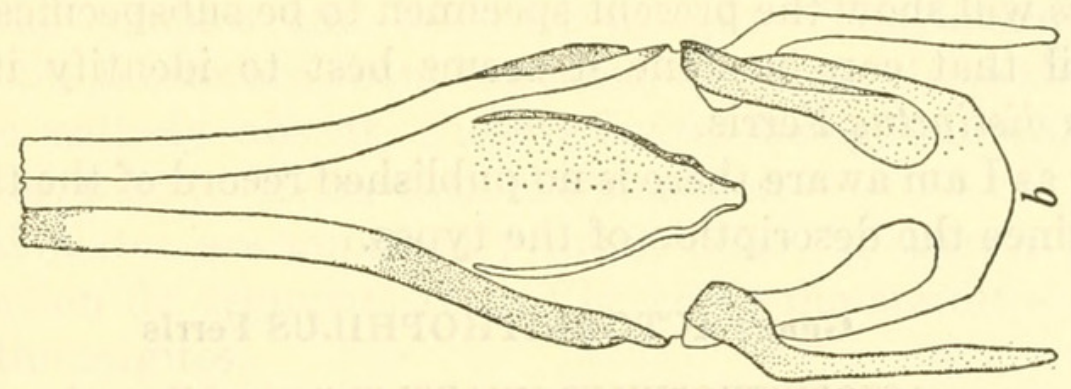

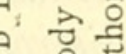

定

○े

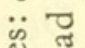

㟧

के i

总

ज्ञ

急

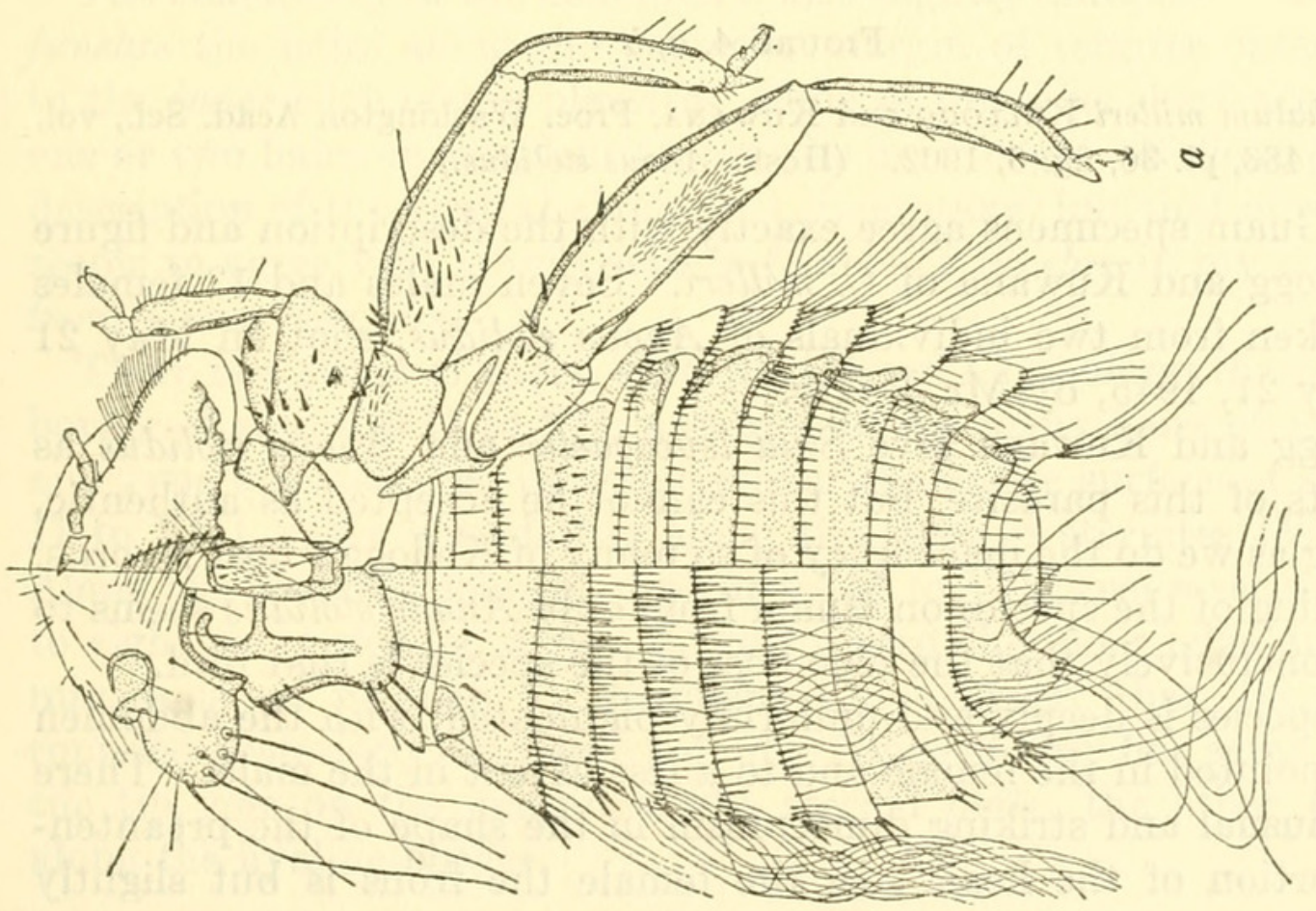

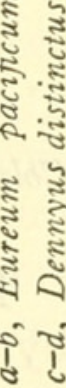


MEASUREMENTS OF TYPE OF EUREUM PACIFICUM

\begin{tabular}{c} 
Structure \\
\hline Body
\end{tabular}

\section{Genus DENNYUS Neumann}

\section{DENNYUS DISTINCTUS Ferris}

Figure $3, c, d$

Dennyus distinctus Ferris, Can. Ent., vol. 48, p. 310, figs. 10a, 15, 1916. (Host: Collocalia sp.)

A single male of what seems to be this rare species was taken on Collocalia inexpectata bartschi, July 29, 1945, by Mr. Baker.

The only discrepancy found in comparing the specimen with Ferris's description was the length, which he gives as $1.9 \mathrm{~mm}$. for the male, while the Guam male is $2.19 \mathrm{~mm}$., being equal to thelength of Ferris's female. It is possible that a direct comparison with the type of distinctus will show the present specimen to be subspecifically distinct, but until that can be done it seems best to identify it merely as Dennyus distinctus Ferris.

As far as I am aware there is no published record of the taking of the species since the description of the types.

\section{Genus ACTORNITHOPHILUS Ferris}

\section{ACTORNITHOPHILUS MILLERI (Kellogg and Kuwana)}

\section{Figure $4, a, b$}

Colpocephalum milleri Kellogg and Kuwana, Proc. Washington Acad. Sci., vol. 4, p. 483, pl. 30, fig. 6, 1902 . (Host: Anous stolidus.)

The Guam specimens agree exactly with the description and figure by Kellogg and Kuwana of $C$. milleri. Seven males and 13 females were taken from two individuals of Anous stolidus, shot on May 21 and July 21, 1945, by Mr. Baker.

Kellogg and Kuwana give Sula leucogaster and Anous stolidus as the hosts of this parasite, but this cannot be accepted as authentic, knowing as we do the inaccuracy of so many of Kellogg's host records. The taking of the species on Guam from only Anous stolidus seems to prove conclusively that the true host of the species is that bird.

The species is deeply and uniformly pigmented, with the abdomen almost pointed in the female and to a less extent in the male. There is an unusual and striking dimorphism in the shape of the preantennary portion of the head. In the female the frons is but slightly 
convex, with square angles at sides, and sides of head straight and slightly divergent to base of antennae; the hairs along frons and sides of head are slender, of fair length, and with three long hairs just in front of the antennary fossae. In the male the frons is strongly rounded, with lateral angles also rounded and with a deep lateral constriction at base of palpi. Around the whole frontal margin, anterior to the constriction, is set a series of heavy spines, with various others on the dorsal surface. In all other respects the heads of the two sexes are similar. Also, in the male the hairs of the abdomen are shorter and heavier, especially on the ventral side.

\section{ACTORNITHOPHILUS FUNEBRE CANDIDUS, new subspecies}

Type.-U. S. N. M. No. 58963, female adult, from Gygis alba, collected by Rollin H. Baker on Guam Island (Marianas), May 25, 1945.

Diagnosis.-Similar to typical funebre in shape of head, thorax, and abdomen and in most of the chaetotaxy but much smaller (body 2.58 by 0.89 , head 0.477 by 0.673 , against body 3.1 by 1.50 , head 0.50 by 0.78 ). It differs further in the absence of the blackish marginal band around the head, this band being present only along the posterior margin of the temples and occipital margin. The lateral pitchy markings on the thorax are about the same, but those of the abdominal pleurites are entirely absent, those sclerites being uniformly light brown in color, a little darker than the sternites.

The tergal plates are apparently much paler, as shown by their posterior portion (in segments II to VI) where the sternites are narrower than the tergites.

The chaetotaxy of the abdomen is also slightly different. In typical funebre the hairs along the posterior margin of tergites extend only to the inner edge of the pleurites, while in candidus there are always one or two hairs on the pleurite, near its inner edge. Kellogg gives no description of the ventral abdominal chaetotaxy, but that of candidus seems to agree very closely with a female of funebre in my collection from Larus serranus.

There is a series of short, stiff, pustulated hairs along the posterior border of sternites II to VII, and in addition many hairs of same size and type are scattered irregularly over the entire surface of sternites II to VIII, more abundantly along the sides of sternites IV and V. Along the posterior margin of pleurites II to VII is set a series of four to eight short slender spines, longer toward the inner edge and most numerous on pleurite V. Segment IX is longer than the others, rounded posteriorly, and with a double fringe of very fine setae around the tip, one on the margin of the sternal plate, the other dorsally along the hyaline border. 
MEASUREMENTS OF ACTORNITHOPHILUS FUNEBRE

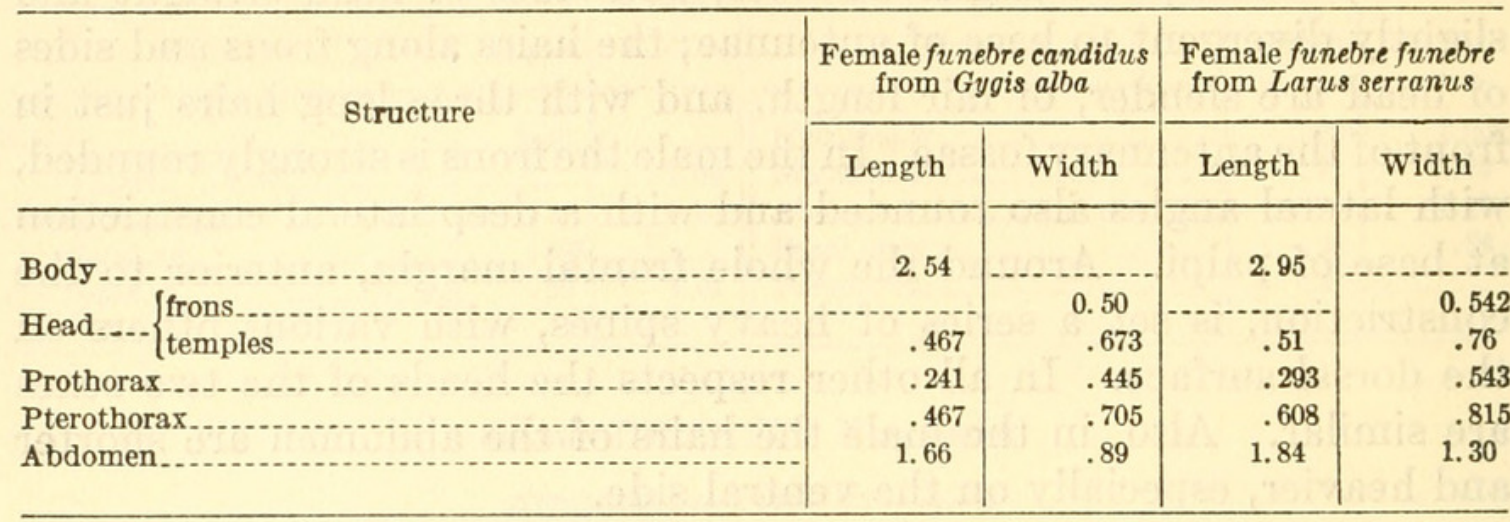

\section{Genus AUSTROMENOPON Bedford}

\section{AUSTROMENOPON BECKI (Kellogg)}

Menopon becki Kellogg, Trans. Amer. Ent. Soc., vol. 32, p. 322, 1906.-Thомрson, Ann. Mag. Nat. Hist., ser. 11, vol. 2, p. 460, figs. 2, 3a, 3c, 1938.

Kellogg's single female of this species (the type) was from Phaëthon aethereus, while he described and figured two males from $P$. rubricauda. In the Guam collection is a series of two males and four females of a Menopon that seems to be this species, taken on Phaëthon lepturus. The males agree very closely with Thompson's description and figures, the only appreciable difference being a slight discrepancy in the number of hairs on the posterior margin of the prothorax (16 instead of 18) and the pterothorax (14 instead of 18). There is also a slight difference in the outline of the head, my specimens having the frons very slightly pointed medially and a greater swelling at the sides, while the occipital margin is more uniformly concave. These differences, however, may be more apparent than real and are hardly worth considering. The remainder of the chaetotaxy is practically the same, as are also the male genitalia, which, in reality, as stated by Thompson, have the apex of the basal plate asymmetrical, with both parameres curving to the right (looking from above). My males show the genitalia exactly as figured by Thompson. There are no special differences between the sexes except in size; even the last abdominal segment is similiarly shaped but bears a double fringe of very fine setae. In the female, however, the gular bars bear six hairs of considerable length, especially the three posterior ones. These six hairs are in addition to the single hair just inside the end of bar. My males have these hairs as given by Thompson, four in number.

\section{Genus MENACANTHUS Neumann}

MENACANTHUS SPINIFERUS (Piaget)

Menopon spiniferum Piaget, Les pédiculines: Suppl., p. 99, pl. 10, fig. 9, 1885. (Host: Cyanocorax chrysops.)

Thompson recorded this parasite from Siturnus vulgaris from Canada, and there are several Old World records of its presence on 

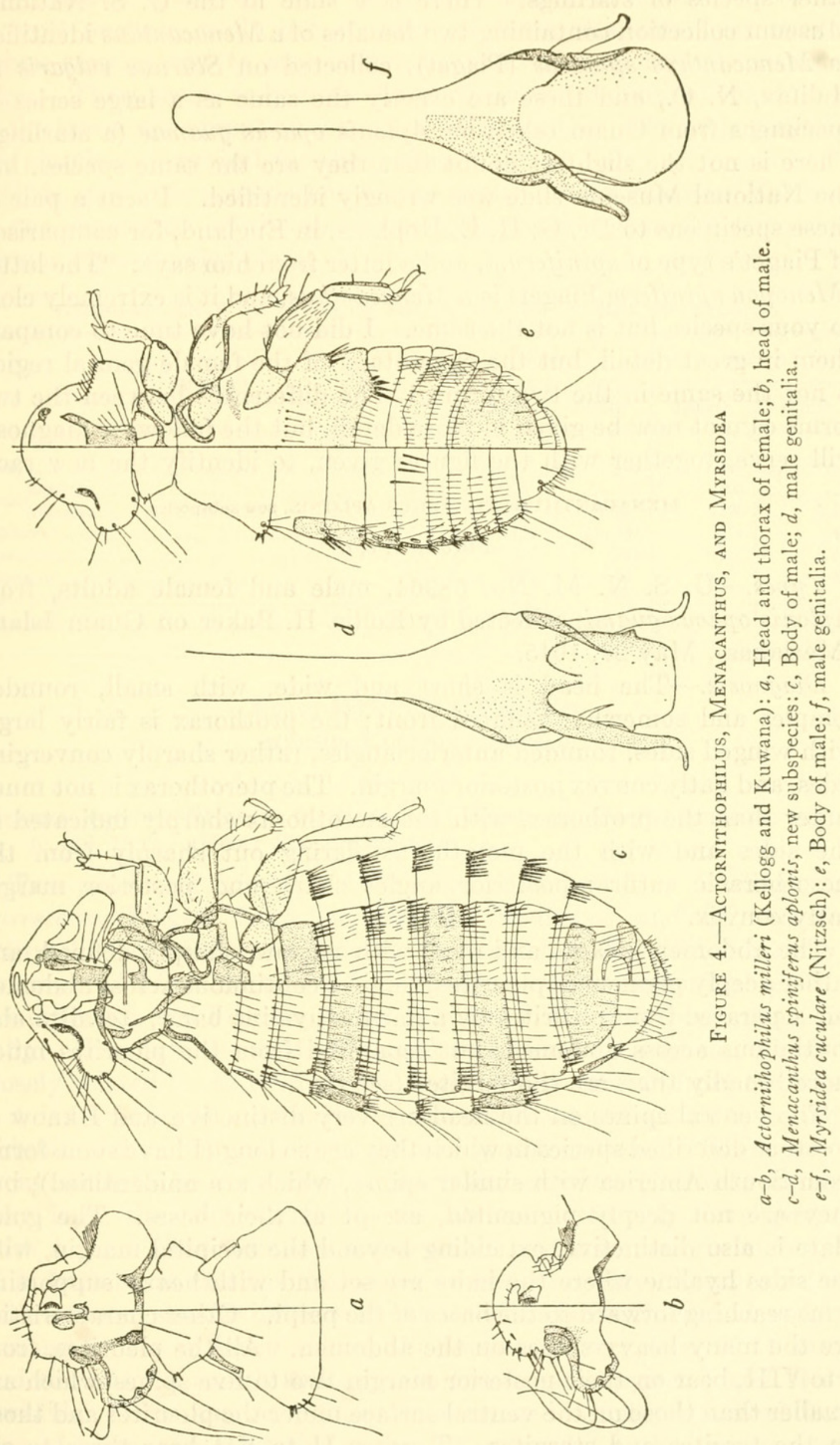
other species of starlings. There is a slide in the U. S. National Museum collection containing two females of a Menacanthus identified as Menacanthus spinosus (Piaget), collected on Siurnus vulgaris at Halifax, N. C., and these are exactly the same as a large series of specimens from Guam taken on Aplonis opacus guamae (a starling). There is not the slightest doubt that they are the same species, but the National Museum slide was wrongly identified. I sent a pair of these specimens to Dr. G. H. E. Hopkins, in England, for comparison of Piaget's type of spiniferum, and a letter from him says: "The latter (Menopon spiniferm Piaget) is a Menacanthus, and it is extremely close to your species but is not the same. I did not have time to compare them in great detail, but the chaetotaxy of the female genital region is not the same in the two forms." The differences between the two forms cannot now be given in more detail, but the following diagnosis will serve, together with the figures given, to identify the new race.

MENACANTHUS SPINIFERUS APLONIS, new subspecies

Figure 4, $c, d$

Types.-U. S. N. M. No. 58964, male and female adults, from Aplonis opacus guami, collected by Rollin H. Baker on Guam Island (Marianas), May 27, 1945.

Diagnosis.-The head is short and wide, with small, rounded temples and somewhat pointed front; the prothorax is fairly large, with winged sides, rounded anterior angles, rather sharply converging sides, and flatly convex posterior margin. The pterothorax is not much larger than the prothorax, with the mesothorax sharply indicated at the sides and with the metathorax flaring out sharply from the mesothoracic suture; posterior angles sharp and posterior margin flatly convex.

The abdomen is large and oval, with narrow, sharply defined, and rather deeply pigmented pleurites; tergites continuous across abdomen but separated from pleurites by a narrow hyaline band; sternites also continuous across abdomen, but separated from the pleurites much more broadly than are the tergites (see fig.).

The ventral spines on the head are very distinctive, and I know of no other described species in which they are so long (I have some forms from South America with similar spines, which are unidentified), but they are not deeply pigmented, except at their bases. The gular plate is also distinctive, extending beyond the occipital margin, with the sides hyaline where the hairs are set and with heavy supporting arms reaching forward to the bases of the palpi. Other characteristics are the many heavy spines on the abdomen. All the pleurites, from I to VIII, bear on their posterior margin two to five spines, which are smaller than those on the ventral surface under the pleurites and those on the tergites and sternites. Tergites II to VII bear three to six 
long, heavy spines on their posterior margin, near their outer (or lateral) portion, while the sternites of same segments bear similar spines ranging two to nine in number, and at their lateral, posterior edge. There seems to be little difference in the abdominal chaetotaxy in the two sexes, except on segments VIII and IX. The male genitalia are simple and typical for the genus.

This species is reminiscent of the genus Machaerilaemus Harrison in the chaetotaxy of the abdomen (the spines) and in the somewhat similar type of gular plate.

MEASUREMENTS OF TYPES OF MENACANTHUS SPINIFERUS APLONIS

\begin{tabular}{|c|c|c|c|c|c|}
\hline \multirow{2}{*}{\multicolumn{2}{|c|}{ Structure }} & \multicolumn{2}{|c|}{ Male } & \multicolumn{2}{|c|}{ Female } \\
\hline & & Length & Width & Length & Width \\
\hline \multicolumn{2}{|l|}{ Body $_{\ldots} . .}$. & & & 1.88 & \\
\hline \multicolumn{2}{|c|}{ Head $\left\{\begin{array}{l}\text { occiput } \\
\text { temples }\end{array}\right.$} & .25 & & .293 & \\
\hline \multirow{2}{*}{\multicolumn{2}{|c|}{$\begin{array}{l}\text { Prothorax } \\
\text { Pterothorax }\end{array}$}} & $\begin{array}{l}.28 \\
.152\end{array}$ & $\begin{array}{l}0.46 \\
.337\end{array}$ & $\begin{array}{l}.326 \\
.174\end{array}$ & $\begin{array}{r}0.553 \\
.423\end{array}$ \\
\hline & & .185 & .412 & .217 & .521 \\
\hline \multicolumn{2}{|c|}{ Abdomen } & .836 & .54 & 1. 27 & .781 \\
\hline \multicolumn{2}{|c|}{ Basal plate. } & .23 & .09 & & \\
\hline \multicolumn{2}{|c|}{ Parameres.. } & .087 & & & \\
\hline
\end{tabular}

\section{Genus MYRSIDEA Waterston}

MYRSIDEA CUCULARE (Nitzsch)

Figure $4, e, f$

Menopon cuculare Nrtzsch, in Burmeister, Handbuch der Entomologie, vol. 2, p. $439,1838 . \quad$ (Host: Sturnus vulgaris.)

Two species of Myrsidea have been described from starlings, $M$. flavescens (Piaget) from Acridotheres cristatellus and M. cuculare (Nitzsch) from Sturnus vulgaris. Harrison has made $M$. flavescens a synonym of $M$. cuculare, but Uchida says that the abdominal sclerites are different, and I dare say that they are distinct, at least subspecifically. The type host of M. cuculare is Sturnus vulgaris, which is closely related to Aplonis opacus (Aplonis was split off from Sturnus).

A large series of a Myrsidea (both sexes) was taken on three individuals of the Guam starling (Aplonis opacus guamae). These specimens seem to be very close to Myrsidea cuculare (Nitzsch) in that they have the first sternite of the abdomen strongly developed in both sexes. This sternite reaches to the posterior margin of tergite II in both sexes and has the posterior margin deeply concave and set with a row of slender hairs, while at each side is the thickened portion bearing four very heavy spines, the inner one very long $(0.11 \mathrm{~mm}$.) and the outer a fourth as long. In the female tergites I and II are invisible; III is narrow, faintly colored, and widely separated from sternal plate I by a hyaline space. Tergites III to VII are strongly 
arched in both sexes; the pleurites are well developed and much darker than the tergites.

The male genitalia are large and heavy, with parameres nearly straight, but slightly tapering and truncate at their tips.

These specimens are also similar to Menopon invadens, taken on Acridotheres tristis (Hawaii), the description and figure of which agree fairly well with the specimens from Guam, but there are certain discrepancies that cannot be reconciled.

MEASUREMENTS OF MYRSIDEA CUCULARE

\begin{tabular}{|c|c|c|c|c|}
\hline \multirow{2}{*}{ Structure } & \multicolumn{2}{|c|}{ Male } & \multicolumn{2}{|c|}{ Female } \\
\hline & Length & Width & Length & Width \\
\hline Body ........... & 1.17 & & 1.54 & \\
\hline Hoad Jocciput... & .293 & 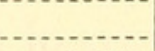 & .326 & \\
\hline Head $\{$ temples.......... & .314 & 0.432 & .35 & 0.50 \\
\hline Prothorax & .13 & .26 & .14 & .303 \\
\hline Pterothorax & .21 & .37 & .33 & .532 \\
\hline Abdomen & .542 & .423 & .825 & .59 \\
\hline Basal plate...................... & .282 & .092 & ...... & $\ldots$. \\
\hline Paramere & .065 & (n) & $\ldots$ & ..... \\
\hline Endomeral sac & .087 & .098 & & \\
\hline
\end{tabular}

MYRSIDEA BAKERI, new species

Figure 5

Types.-U. S. N. M. No. 58965, male and female adults, from Corvus kubaryi, collected by Rollin H. Baker on Guam Island (Marianas), June 1945.

Diagnosis.- Similar in a general way to the type of $M$. subaequalis (Lyonet) (=M. mesoleuca Nitzsch) but differing in many particulars. It is a strikingly marked species, with the sexes highly dimorphic and with abdominal segment $I$ in the female peculiarly developed, much wider than segments III, IV, and V and fused with II. The chaetotaxy of the abdomen in the female is strongly developed, with most of the hairs very long and coarse. Sternite I is thickened and deeply pigmented and bears on its posterior margin and sternal surface a series of long, coarse hairs, in addition to the four long spines at each side. The posterior margin of the fused segments II and III is without hairs on dorsal surface, but IV to VIII bear a series of long, strong hairs rather widely spaced. Sternites III to VIII are thickly set with very coarse hairs along their posterior margins, especially on lateral portions. There are no well-defined pleural plates, except on I, II, and III, the tergites being fused with the sternites at each side; tergites II to VIII are separated medially, but the sternites are continuous, although faintly indicated medially on II to IV, and all are widely separated from one another by hyaline areas. 

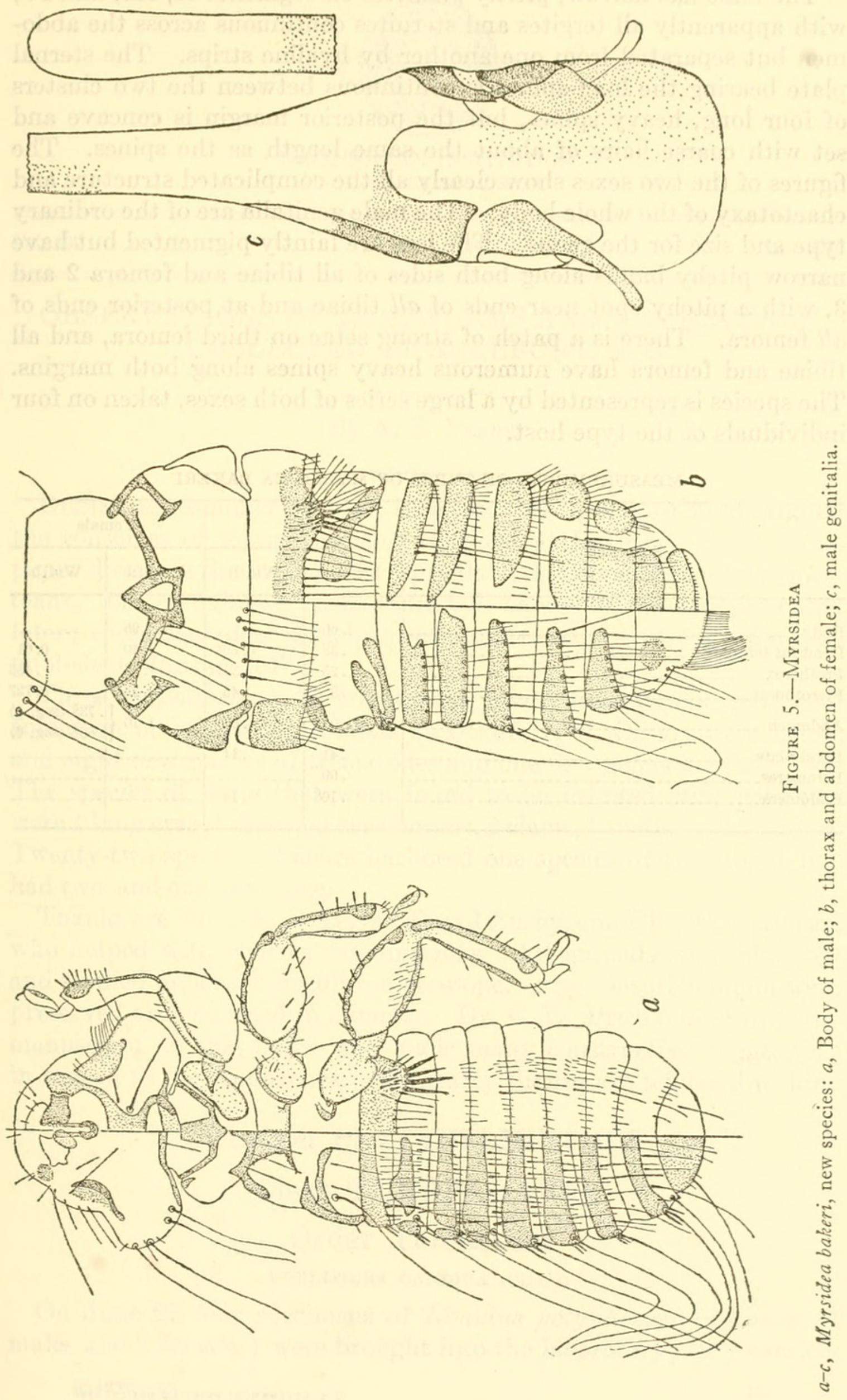
The male has narrow, pitchy pleurites on segments II, III, and IV, with apparently all tergites and sternites continuous across the abdomen but separated from one another by hyaline strips. The sternal plate bearing the long spines is continuous between the two clusters of four long, heavy spines, but the posterior margin is concave and set with coarse hairs of about the same length as the spines. The figures of the two sexes show clearly all the complicated structure and chaetotaxy of the whole body. The male genitalia are of the ordinary type and size for the genus. The legs are faintly pigmented but have narrow pitchy bands along both sides of all tibiae and femora 2 and 3 , with a pitchy spot near ends of all tibiae and at posterior ends of all femora. There is a patch of strong setae on third femora, and all tibiae and femora have numerous heavy spines along both margins. The species is represented by a large series of both sexes, taken on four individuals of the type host.

MEASUREMENTS OF TYPES OF MYRSIDEA BAKERI

\begin{tabular}{|c|c|c|c|c|}
\hline \multirow{2}{*}{ Structure } & \multicolumn{2}{|c|}{ Male } & \multicolumn{2}{|c|}{ Female } \\
\hline & Length & Width & Length & Width \\
\hline Body & 1. 60 & & 1.96 & \\
\hline Head (at temples) & .38 & 0.564 & .40 & 0.61 \\
\hline Prothorax & .25 & .337 & .26 & .456 \\
\hline Pterothorax................. & .326 & .45 & .35 & .727 \\
\hline Abdomen....... & 1.02 & .52 & 1.10 & $\left\{\begin{array}{l}.738 \text { (seg. 1) } \\
.608 \text { (seg. 6) }\end{array}\right.$ \\
\hline Basal plate.......... & .41 & .11 & & 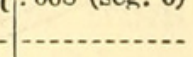 \\
\hline Parameres. & .09 & $\ldots$ & & 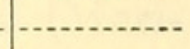 \\
\hline Endomera. & .108 & .13 & & \\
\hline
\end{tabular}




\section{$2 \mathrm{BHL}$ Biodiversity Heritage Library}

Carriker, Melbourne Armstrong. 1949. "On a collection of Mallophaga from Guam, Marianas Islands." Proceedings of the United States National Museum 100(3254), 1-24. https://doi.org/10.5479/si.00963801.100-3254.1.

View This Item Online: https://www.biodiversitylibrary.org/item/53452

DOI: https://doi.org/10.5479/si.00963801.100-3254.1

Permalink: https://www.biodiversitylibrary.org/partpdf/52100

\section{Holding Institution}

Smithsonian Libraries

\section{Sponsored by}

Smithsonian

\section{Copyright \& Reuse}

Copyright Status: Public domain. The BHL considers that this work is no longer under copyright protection.

This document was created from content at the Biodiversity Heritage Library, the world's largest open access digital library for biodiversity literature and archives. Visit BHL at https://www.biodiversitylibrary.org. 